\title{
PRINSIP PERHITUNGAN ZAKAT SAHAM PERUSAHAAN SEKTOR NON-KEUANGAN
}

\author{
Lalu Ahmad Ramadani \\ Fakultas Ekonomi dan Bisnis Islam Universitas Islam Negeri Mataram \\ laluahmadramadani@uinmataram.ac.id
}

\begin{abstract}
The purpose of this study is to examine the mechanism for calculating zakat on nonfinancial sharia shares based on sectors outside the financial sector, consisting of trading, industrial, property, agricultural and health companies. This study uses a literature study approach using descriptive qualitative analysis methods. This study found that the principle of non-obligatory zakat in financial companies refers to the legal provisions of fiqh, but the provisions of compulsory zakat have differences in each industrial sector, such as the hospital industry where the zakat rate is the difference between the total annual income and annual hospital expenditure

Keywords: Shares and Company Zakat

\section{PRINSIP PERHITUNGAN ZAKAT SAHAM PERUSAHAAN SEKTOR NON-KEUANGAN}

ABSTRAK

Tujuan dari penelitian ini adalah untuk mengkaji mengkaji mekanisme perhitungan zakat saham syariah non-keuangan berdasarkan sektor yang berada di luar sektor keuangan, terdiri dari perusahaan Perdagangan, Industri, Properti, Pertanian dan Kesehatan. Penelitian ini menggunakan pendekatan studi literature dengan menggunakan metode analisis kualitatif deskriptif. Penelitian ini menemukan bahwa prinsip tidak wajib zakat pada perusahaan keuangan, mengacu pada ketentuan hukum fiqih, namun ketentuan wajib zakat memiliki pebedaan pada setiap sektor industri, seperti industri rumah sakit yang Takaran zakatnya adalah selisih antara pemasukan total tahunan dan pengeluaran tahunan rumah sakit.
\end{abstract}

Kata kunci: Zakat Saham dan Perusahaan 


\section{A. Pendahuluan}

Menilik sejarah wajibnya zakat, secara inheren, wajib zakat dalam Syariah (hukum) ada sebelum kedatangan Rasulullah SAW dan terjadi secara bertahap. Zakat mulai secara resmi diwajibkan pada tahun kedua hijrah (migrasi) Rasulallah SAW ke Madinah. ${ }^{1}$

Objek (benda) sebagai sumber wajib zakat mulai diberlakukan pada masa awal dan terbatas pada sumber-sumber tradisional yaitu: emas, perak, gandum, palem, jagung, unta, sapi, kambing dan produk-produknya. Namun, realitas sosial-budaya dan ekonomi masyarakat saat ini, jauh berbeda dari zaman Rasulullah SAW. Bahkan, bentuk kepemilikan dan kepentingan suatu benda, telah banyak mengalami perubahan dan fleksibel. Dalam keadaan tertentu, Islam memiliki fleksibelitas dalam menyikapi perubahan zaman. Selain itu, keterbukaan (ijtihad) telah memberi jalan untuk memperluas benda sebagai sumber objek zakat yaitu seperti saham syariah, yang dewasa ini mengalami peningkatan yang cukup pesat. Hal ini berdasarkan fatwa First Zakat Conference yang diadakan di Kuwait pada tahun 1984 tentang sumber zakat.

Sejarah menunjukkan, keberadaan saham perusahaan di negara-negara barat, sudah ada berabad-abad lamanya. Namun, di negara-negara Muslim, perkembangan mereka baru terlihat pada abad ke-20. ${ }^{2}$ Hingga saat ini, Perkembangan investor saham syariah selama 4 (empat) tahun terakhir rata-rata meningkat $100 \%$ setiap tahunnya. Jumlah investor saham syariah pada tahun 2018 mencapai 45.000 investor atau meningkat $96 \%$ dari tahun 2017 dengan jumlah investor sebanyak 23.000 orang. Berdasarkan report dari Otoritas Jasa Keuangan (OJK), Indonesia memiliki 358 saham syariah. Namun, hanya ada satu dari 358 saham yang menerbitkan zakat saham. Sebagai objek zakat baru, sebenarnya telah dilegitimasi oleh kebijakan zakat di Indonesia. ${ }^{3}$

Tabel. 1: Perkembangan Investor Saham Syariah

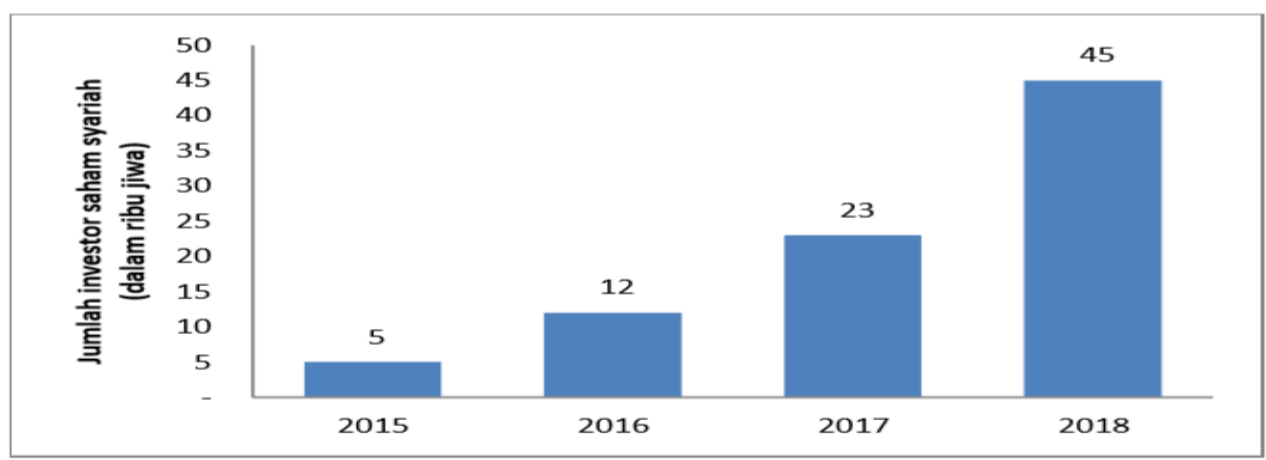

Sumber: Laporan Tahunan Bursa Efek Indonesia (2019) diolah.

Data perkembangan jumlah saham syariah dan investor tersebut tentunya menjadi peluang besar sebagai sumber zakat di Indonesia. Hal tersebut disebabkan menurut

\footnotetext{
${ }^{1}$ Endut, Wan Anisah, Suraya Ismail, and Ahmad Othman. "Method of Zakat Assessment on Shares in Malaysia: An Overview." International Journal of Education and Research Vol. 3 No.6` (2015): 327-334.

${ }^{2}$ Islahi, Abdul Azim, and Mohammed Obaidullah. "Zakah on stocks: some unsettled issues." Journal of King Abdulaziz University: Islamic Economics 17.2 (2004).

3 Dakhoir, Ahmad. "Al-Qardawi's Thought on Zakat of Stocks in a Modern Industry: an Experience of Indonesia." Al-Manahij: Jurnal Kajian Hukum Islam 13.2 (2019): 159-168.
} 
Undang-undang Nomor 23 Tahun 2011 tentang Pengelolaan Zakat disebutkan bahwa salah satu objek zakat adalah zakat perusahaan. Data perkembangan dan nilai transaksi saham syariah diatas dapat menjadi salah satu potensi zakat di Indonesia. Menurut BAZNAS tahun 2019, potensi zakat di Indonesia mencapai Rp. 233,8 triliun ${ }^{4}$. Dari jumlah tersebut, potensi zakat perusahaan yang sudah dihitung adalah zakat dari perusahaan BUMN yaitu sebesar Rp. 6,27 triliun, sedangkan zakat dari perusahaan publik belum dapat dipetakan.

Beberapa riset yang mengkaji zakat perusahaan antara lain disampaikan oleh Harfiah $(2009)^{5}$, Nasir $(2015)^{6}$ dan Andriani, Rakhmawati dan Fahmi (2016) ${ }^{7}$. Ketiga penelitian tersebut lebih memfokuskan pada penggunaan berbagai metode perhitungan zakat perusahaan, misalnya metode yang diadopsi dari AAOIFI, T.E Gambling dan RA Karim, metode Yusuf Qardhawi, metode Hafiduddin ataupun metode yang lazim digunakan di Indonesia yatiu 2,5\% dari pendapatan sebelum zakat dan pajak. Pada kajian ini lebih mengarah pada penggunaan metode Fiqih Zakat Perusahaan untuk selanjutnya dihitung zakat per lembar saham yang dibayarkan oleh pemegang saham.

\section{B. METODE PENELITIAN}

Zakat saham perusahaan non-keuangan dapat ditentukan dengan prinsip perhitungan yang mengacu pada ketentuan fiqih zakat perusahaan yang disusun oleh BAZNAS yaitu sebagai berikut: ${ }^{8}$

1. Menentukan tanggal tibanya haul yaitu tanggal yang dipilih untuk menghitung zakat. Haul ini harus memiliki awal dan akhir dengan jarak waktunya 12 bulan. Pada tanggal yang menjadi akhir dari satu haul, disiapkan transaksi penutup dan juga neraca laporan keuangan. Penggunaan haul juga berlaku untuk penentuan dan pengukuran takaran (wi'a) zakat saham berdasarkan liabilitas di akhir haul, yang tentunya harus dikurangi dari harta zakat sesuai dengn hukum, prinsip dan dasardasar yang telah dijelaskan. Data tersebut dapat diperoleh dari kumpulan current liabilities pada laporan neraca umum atau pusat keuangan.

Ketentuan di atas, hampir sama dengan fatwa yang dikeluarkan oleh Komite Syariah untuk Negeri Melaka pada tanggal 2 April 2009, bahwa metode penilaian zakat pada saham pada Komite Syariah Melaka membagi saham di mana wajib zakat dibagi menjadi dua kategori. Pertama, saham yang diperdagangkan sepanjang haul di mana metode penilaian zakat atas saham didasarkan pada penjualan saham setelah dikurangi biaya pembelian saham. Setelah memenuhi kondisi nisab dan haul, zakat dikenakan biaya 2,5 persen. Pembayaran zakat ditentukan berdasarkan modal dagang yang nilainya dihitung berdasarkan harga pasar saat ini. ${ }^{9}$ Kedua, saham yang masih dimiliki pada akhir haul. Metode penilaian didasarkan pada nilai yang lebih

${ }^{4}$ Badan Amil Zakat Nasional (PUSKAS-BAZNAS). Indikator Pemetaan Potensi Zakat. BAZNAS. Jakarta, 2019.

${ }^{5}$ Harfiah. (2009). Perhitungan Zakat Shareholder Perusahaan (Studi Kasus Pada Perusahaan Jasa, Dagang, dan Industri yang Listing di Jakarta Islamic Index. Fakultas Ekonomi Unhas. Makasar

${ }^{6}$ Laode Arahman Nasir. (2015). Analisis Perhitungan Zakat Perusahaan (Studi Kasus Pada MasingMasing Sektor Perusahaan Yang Tercatat Di Bursa Efek Indonesia). Fakultas Ekonomi dan Bisnis Unhas. Makasar.

${ }^{7}$ Andriani, Aneta Rakhmawati, Muhammad Yasir Fahmi. (2016). Analisis Potensi Zakat Entitas Pada Bank Umum Syariah Di Indonesia. Prosiding Seminar Nasional ASBIS 2016 Politeknik Negeri Banjarmasin

${ }^{8}$ Fiqih Zakat Perusahaan yang dikeluarkan oleh BAZNAS pada tahun 2018

9 Amalia, Sheila. "Exploring Strategies to Optimize the Collection of Zakat on Shares in Indonesia." Tazkia Islamic Finance and Business Review 12.2 (2018). 
rendah antara harga pasar dan harga pembelian. Namun, jika sulit untuk menentukan harga yang lebih rendah antara harga pasar dan harga pembelian, maka harga saham pada akhir haul yang akan digunakan. Setelah memenuhi persyaratan nisab dan haul, zakat dikenakan biaya 2,5 persen. ${ }^{10}$

2. Menentukan dan mengukur harta zakat dengan menganalisis harta yang memenuhi syarat wajib zakat yang diambil dari kumpulan aset lancar pada neraca umum atau pusat keuangan.

3. Menentukan dan mengukur jumlah nishab. Ijma' para fuqaha klasik dan kontemporer, jumlahnya setara dengan 85 gram emas murni, dinilai berdasarkan harga emas di pasar pada saat jatuhnya haul.

4. Menentukan persentase zakat, berupa jumlah yang diambil dari takaran zakat. Ijma' para fuqaha klasik dan kontemporer jumlahnya adalah 2,5\% berdasarkan penanggalan hijriah atau $2,575 \%$ berdasarkan penanggalan masehi.

5. Menghitung jumlah zakat yang wajib dikeluarkan dengan cara mengalikan takaran zakat dengan persentase zakat.

6. Menentukan beberapa hal:

a. Pada perusahaan rekanan (partnership company) seperti perusahaan rekanan umum (general partnersip company) dan Perseroan terbatas (limited partnersip company) mitra/pemegang saham akan menanggung bagian zakatnya masingmasing yang difasilitasi manajemen. Dimana mereka akan mendapat pemberitahuan dari manajemen.

b. Pada perusahaan join saham (joint stock company) ditanggung oleh para pemilik saham. Dimana jumlah zakat dibagi sesuai dengan jumlah saham. Para pemegang saham akan diberitahu tentang hal ini oleh manajemen, sedangkan proses zakatnya dilakukan oleh masing-masing pemegang saham.

\section{Analisis dan pembahasan}

Penghitungan zakat saham perusahaan non-keuangan, dibedakan berdasarkan jenis kegiatan yang dilaksanakan perusahaan. Berikut dijelaskan metode perhitungan zakat perusahaan berdasarkan jenis kegiatan yang dilakukan:

1. Zakat saham Perusahaan Perdagangan

Secara universal, tujuan perusahaan perdagangan melakukan aktivitas jual beli adalah profit maximation. Maka berlaku baginya hukum fiqih yaitu:

Zakat perusahaan dagang ditentukan pertahun. Penentuan zakat, Tidak dikenakan (wajib) zakat pada aset tetap untuk penunjang usaha, baik yang bersifat materi maupun non materi. Tetapi dikenakan (wajib) zakat pada harta zakat berupa aset lancar seperti barang - barang, piutang, wesel, investasi dan uang tunai di bank. Wajib zakat perusahaan perdagangan dapat diuraikan berdasarkan beberapa ketentuan sebagai berikut:

a. Penilaian terhadap harta zakat adalah berdasarkan nilai pasar yang sedang berlaku. Namun, setelah dikurangi dari Liabilitas harta zakat perusahaan dagang.

${ }^{10}$ Endut, Wan Anisah, Suraya Ismail, and Ahmad Othman. "Method of Zakat Assessment on Shares in Malaysia: An Overview." International Journal of Education and Research 3.6 (2015): 327-334. 
b. Nishab zakat setara dengan 85 Gram emas murni. Jika dalam nominal rupiah, 1 gram setara dengan Rp. 926.000. ${ }^{11}$ Sehingga, dapat ditotalkan nisab zakat sebesar Rp. 78.710.000,-

c. Persentase zakat adalah 2,5 berdasarkan penanggalan hijriah dan 2,575 berdasarkan penanggalan masehi.

d. Zakat dibagi setelah dihitung nilainya untuk masing-masing rekan pada perusahaan rekanan dan bagian saham pada perusahaan join saham.

2. Zakat Saham Perusahaan Industri

Perusahaan industri merupakan perusahaan yang melibatkan bahan baku, pekerjaan, alat-alat, perlengkapan dan sejenisnya serta menjual produk-produknya untuk mendapatkan keuntungan (profit). Maka, dalam perhitungan zakatnya akan menggabungkan antara produksi dan perdagangan. Hal yang perlu diperhatikan yaitu: tidak wajib zakat pada Aset tetap yang digunakan di dalam produksi dan wajib harta zakat pada barang-barang, piutang, investasi, uang tunai, dengan syarat sebagai berikut:

a. Wajib zakat pada produk jadi, produksi (belum jadi) berdasarkan opini ahli dan bahan baku yang dinilai berdasarkan nilai pasar secara keseluruhan.

b. Tidak wajib zakat pada peralatan produksi yang digunakan, seperti minyak pelumas, alat-alat kebersihan dan barang yang telah rusak dan tidak bisa dijual. Biaya-biaya yang digunakan seperti: biaya penelitian, kajian, percobaan dan sejenisnya yang digunakan sebelum memulai proses produksi.

3. Zakat Saham Perusahaan Properti

Perusahaan konstruksi dan investasi properti biasanya menjalankan usahanya dengan membeli tanah kemudian membangun bangunan secara fisik seperti pemukiman, kawasan bisnis maupun perkantoran dan sebagainya, kemudian menjualnya untuk mendapatkan keuntungan. Maka, diterapkan atasnya hukum-hukum zakat perdagangan dan juga industri. Hal-hal yang perlu diperhatikan yaitu:

a. Aset tetap yang mensupport pembangunan ini tidak tunduk kepada harta zakat.

b. Harta zakat terletak pada produksi yang telah sempurna (jadi), yang sedang dikerjakan, bahan baku, piutang dan uang tunai sebagaimana berikut: Unit-unit yang telah selesai dibangun dan belum terjual, dinilai berdasarkan nilai pasarnya, harga pasar saat itu. Sedangkan, unit yang belum selesai dibangun, dinilai berdasarkan nilai (Konstruksi bahan baku, bahan bangunan dan sejenisnya) dan kondisi saat itu berdasarkan keterangan ahli.

Zakat tidak wajib pada jaminan penawaran, tender dan pekerjaan karena ia merupakan harta yang terikat dan tertahan. Sedangkan, diantara liabilitas yang harus dipotong dari harta zakat adalah uang muka yang diberikan oleh kostumer yang belum menerima unit properti mereka. Begitupula dengan hutang, wesel bayar, pengeluaran-pengeluaran wajib, uang yang dikhususkan sebagai cadangan ketika adanya kenaikan harga, dan yang sejenisnya.

4. Zakat Saham Perusahaan Pertanian

Aktivitas usaha pertanian biasanya dilakukan dalam bentuk budidaya tanaman/hewan ternak yang bertujuan untuk memperoleh keuntungan. Pada perusahaan ini, diterapkan zakat pertanian dan buah-buahan hasil bumi. Diantara hal penting untuk diperhatikan pada aktivitas usaha pertanian adalah Tidak wajib zakat pada nilai tanah yang dimanfaatkan untuk pertanian dan pada properti yang

${ }^{11}$ www.logammulia.com, Akses 20 Mei 2020. 
dibangun, alat-alat, mesin, peralatan, mobil, perabot dan semua hal yang terdapat di lahan pertanian karena termasuk aset tetap.

Sedangkan, wajib zakat berdarkan hasil pada musim panen dengan nisbah zakat pertanian dan buah-buahan senilai dengan 5 ausuq, yang setara dengan $653 \mathrm{Kg}$ atau 50 Kilah, yang dinilai berdasarkan harga yang berlaku saat mengeluarkan zakat. Persentase zakat pertanian dan buah-buahan adalah: jika pertaniannya diairi dengan alat dan sumur mesin atau yang sejenisnya: 5\% dan biaya pengeluaran yang berkaitan dengan lahan pertanian selama musim menanam menjadi pengurang harta zakat. Penentuan harga rata-rata saham yang akan digunakan sebagai estimasi terbaik untuk perhitungan jumlah saham yang dikenakan pajak. ${ }^{12}$

5. Zakat Saham Perusahaan Kesehatan

Aktivitas layanan kesehatan seperti rumah sakit dianggap sebagai aktivitas investasi modern yang bertujuan untuk mendapatkan keuntungan. Biasanya, rumah sakit besar berbentuk perusahaan join saham antara investor atau rumah sakit lainnya sebagai partnership. Dalam pembayaran zakat, terdapat beberapa yang harus diperhatikan dalam penentuan wajib zakat perusahaan kesehatan/rumah sakit. Sama halnya dengan perusahaan dagang, wajib zakat perusahaan kesehatan, tidak dibebankan pada aset-aset tetap rumah sakit dan peralatan keperawatan.

Takaran zakat pada perusahaan jenis ini adalah selisih antara pemasukan total tahunan dan pengeluaran tahunan rumah sakit. Dihitung dengan cara: Takaran zakat $=$ pemasukan tahunan - (biaya dan pengeluaran). Nishab zakat rumah sakit adalah nishab perdagangan dan industri, yakni setara dengan 85 Gram emas murni. Persentase zakat rumah sakit adalah 2,5\% berdasarkan penanggalan hijriah dan nilai pasar aset, ${ }^{13}$ dikiaskan dengan zakat perdagangan.

\section{Penutup}

Penetapan perhitungan zakat saham pada benda tidak wajib zakat mengacu pada ketentuan fiqih tentang zakat. Namun pada ketentuan wajib zakat saham terdapat beberapa perbedaan antara Zakat saham Perusahaan Perdagangan, Zakat Saham Perusahaan Industri, Zakat Saham Perusahaan, Properti, Zakat Saham Perusahaan Pertanian dan terlebih lagi Zakat Saham pada Perusahaan Kesehatan, yang merupakan industri yang berorientasi pada sektor jasa.

\section{Daftar Pustaka}

Amalia, Sheila. "Exploring Strategies to Optimize the Collection of Zakat on Shares in Indonesia." Tazkia Islamic Finance and Business Review 12.2 (2018).

Andriani, Aneta Rakhmawati, Muhammad Yasir Fahmi. (2016). Analisis Potensi Zakat Entitas Pada Bank Umum Syariah Di Indonesia. Prosiding Seminar Nasional ASBIS 2016 Politeknik Negeri Banjarmasin.

12 Amalia, Sheila. "Exploring Strategies to Optimize the Collection of Zakat on Shares in Indonesia." Tazkia Islamic Finance and Business Review 12.2 (2018).

13 Rahman, Shafiqur. "Ethical Investment in the Stock Market: Halal Investing and Zakat on Stocks." Available at SSRN 2504832 (2014). 
Badan Amil Zakat Nasional (PUSKAS-BAZNAS). (2019). Indikator Pemetaan Potensi Zakat. BAZNAS. Jakarta.

Dakhoir, Ahmad. "Al-Qardawi's Thought on Zakat of Stocks in a Modern Industry: an Experience of Indonesia." Al-Manahij: Jurnal Kajian Hukum Islam 13.2 (2019): 159168.

Endut, Wan Anisah, Suraya Ismail, and Ahmad Othman. "Method of Zakat Assessment on Shares in Malaysia: An Overview." International Journal of Education and Research 3.6 (2015): 327-334.

Fiqih Zakat Perusahaan yang dikeluarkan oleh BAZNAS pada tahun 2018.

Harfiah. (2009). Perhitungan Zakat Shareholder Perusahaan (Studi Kasus Pada Perusahaan Jasa, Dagang, dan Industri yang Listing di Jakarta Islamic Index. Fakultas Ekonomi Unhas. Makasar.

Islahi, Abdul Azim, and Mohammed Obaidullah. "Zakah on stocks: some unsettled issues." Journal of King Abdulaziz University: Islamic Economics 17.2 (2004).

Laode Arahman Nasir. (2015). Analisis Perhitungan Zakat Perusahaan (Studi Kasus Pada Masing-Masing Sektor Perusahaan Yang Tercatat Di Bursa Efek Indonesia). Fakultas Ekonomi dan Bisnis Unhas. Makasar.

Rahman, Shafiqur. "Ethical Investment in the Stock Market: Halal Investing and Zakat on Stocks." Available at SSRN 2504832 (2014). 